\title{
PENGARUH TERAPI MUROTTAL AL-QUR'AN TERHADAP PENINGKATAN KONSENTRASI BELAJAR PADA MAHASISWA PRODI S1 KEPERAWATAN TINGKAT II STIKES YPIB MAJALENGKA TAHUN 2019
}

\author{
Yophi Nugraha \\ STIKes YPIB Majalengka \\ yophi.nugraha86@gmail.com
}

\begin{abstract}
Abstrak
Keberhasilan suatu proses belajar dipengaruhi oleh konsentrasi. Tujuan penelitian ini untuk mengetahui pengaruh terapi murottal Al-Qur'an terhadap peningkatan konsentrasi belajar mahasiswa tingkat II S1 keperawatan STIKes YPIB Majalengka. Desain penelitian ini yaitu Quasi Eksperimen Design rancangan Non Equaivalent Control Group dengan sampel yaitu 36 mahasiswa kelompok eksperimen dan 36 mahasiswa kelompok kontrol dengan menggunakan Purposive Sampling. Teknik pengumpulan data menggunakan kuesioner Army Alpha. Analisa data menggunakan uji statistik Uji Wilcoxon. Hasil pengolahan data pada kelompok eksperimen didapatkan nilai $\rho$ value $=0.000$ atau $\rho<0.05$. Jadi dapat disimpulkan bahwa ada pengaruh terapi murottal Al-Qur'an terhadap peningkatan konsentrasi belajar mahasiswa tingkat II S1 keperawatan STIKes YPIB Majalengka.
\end{abstract}

Kata Kunci : Terapi Murottal Al-Qur'an, Konsentrasi

Pendahuluan

Dalam suatu proses belajar, konsentrasi itu merupakan salah satu faktor terpenting dalam mengikuti suatu proses pembelajaran supaya proses pembelajaran itu tercapai dan berhasil. Konsentrasi adalah usaha setiap individu untuk memfokuskan perhatian terhadap suatu objek, sehingga dapat dimengerti, dipahami, dan meminimalisir perhatian yang terpecah (Julianto et al., 2014).
Ciri-ciri seseorang yang mengalami gangguan konsentrasi diantaranya sering bosan terhadap suatu hal, selalu berpindah tempat, tidak mendengarkan ketika diajak berbicara, mengalihkan pembicaraan, sering mengobrol, dan mengganggu teman lainnya (Rahmayani, 2017).

Konsentrasi belajar dipengaruhi oleh dua faktor yaitu faktor internal dan faktor eksternal (Linasari, 2015). Faktor internal yang berasal dari dalam diri sendiri 
JOURNAL OF NURSING PRACTICE AND EDUCATION

VOL. 01 No. 01, DESEMBER 2020
Ciptaan disebarluaskan di bawah

Lisensi Creative Commons Atribusi-

NonKomersial-BerbagiSerupa 4.0 Internasional. sebagai penentu konsentrasi seseorang yang terdiri dari kondisi fisik yang sehat, mengkonsumsi makanan yang sehat dan bergizi, tidak memiliki masalah yang berat, serta memiliki motivasi untuk belajar. Sedangkan faktor eksternal merupakan faktor dari luar yaitu sarana dan prasarana yang tidak memadai seperti media pembelajaran dan ruangan kelas yang sempit dan tidak memiliki AC sehingga mengganggu kenyamanan, cara mengajar dosen yang tidak menarik hanya menggunakan metode ceramah, mencatat dan penugasan (Noviati et al., 2019).

Data WHO 2018 menunjukkan lebih dari 150 juta orang mengalami gangguan mental emosional, sedangkan di Indonesia sendiri prevalensi gangguan mental emosional pada usia $\geq 15$ tahun ditemukan peningkatan sebesar 3,8\% yang tadinya pada Riskesdas tahun 2013 hanya $6,0 \%$ sehingga menjadi $9,8 \%$. Untuk provinsi Jawa Barat juga dari tahun 20132018 mengalami peningkatan sebesar $\geq$ 2,0\% (Riskesdas, 2018).

Goldfried dan Davidson dalam Aini, (2018) menyatakan bahwa relaksasi adalah salah satu teknik dalam terapi perilaku untuk mengurangi ketegangan dan kecemasan. Perkembangan terbaru menunjukan bahwa relaksasi bisa dikombinasi dengan dzikir. Metode ini dikenal dengan relaksasi religius. Salah satu alternatif terapi baru sebagai terapi relaksasi bahkan lebih baik dibandingkan dengan terapi seperti musik adalah murottal AlQur'an (Julianto et al., 2014).

Murottal Al-Qur'an adalah pembacaan ayat Al Quran dengan menggunakan tajwid yang baik dan benar serta berirama oleh seorang qori'. Terapi audio murotal al Quran adalah kegiatan membaca asmaul husna dan mendengarkan rekaman bacaan ayat al Quran yang dilagukan oleh seorang qori' atau pembaca al Quran sesuai dengan tajwid yang baik dan benar. Alunan bacaan al quran yang merdu mampu memberikan rasa nyaman dan tenang (Yakub, 2016). Lantunan murottal al quran mengandung unsur suara manusia yang merupakan instrumen penyembuhan yang menakjubkan karena dapat menurunkan hormon-hormon stress dan mengaktifkan hormon endorfin alami serta dapat meningkatkan perasaan rileks (Rusmini et al., 2018).

Terapi Murottal al-Quran dilakukan 1 kali dalam sehari selama 3 hari berturutturut menggunakan file mp3 dengan audio speaker, kemudian diputar selama 15 menit terdiri dari surah Al-Fatihah selama 1 menit, Ar-Rahman selama 12 menit, Al- 
JOURNAL OF NURSING PRACTICE AND EDUCATION

Vol. 01 No. 01, DESEMBER 2020
Ciptaan disebarluaskan di bawah

Lisensi Creative Commons Atribusi-

NonKomersial-BerbagiSerupa 4.0

Internasional.
Ikhlas, Al-Falaq dan An-Naas terakhir selama 2 menit (Wuryaningsih., Emi, 2017).

Studi pendahuluan yang dilakukan pada tanggal 21 maret 2019 dengan metode wawancara ke 10 mahasiswa Program Studi S1 keperawatan tingkat II A dan B, mereka mengatakan kesulitan untuk fokus atau kesulitan untuk berkonsentrasi dalam proses belajar karena beberapa faktor mulai kondisi fisik yang meliputi kelelahan, sakit, rasa lapar, insomnia dan menstruasi. Kondisi psikologis meliputi motivasi, suasana hati dan dukungan keluarga. Kemudian atmosfer pembelajaran meliputi persepsi mahasiswa terhadap dosen, jumlah mahasiswa, posisi duduk, pengaruh teman, kepadatan jadwal kuliah, penggunaan gadget dan masalah keuangan.

Sepuluh mahasiswa yang di wawancara hasilnya ada 9 (90\%) yang kehilangan konsentrasi pada saat belajar dan akhirnya mereka harus melakukan perbaikan nilai. Di dapatkan pada kelas tingkat II A ada 34 Mahasiswa dan di kelas tingkat II B terdapat 30 Mahasiswa yang harus mengikuti remedial salah satu matkul 2-3 kali untuk mencapai standar nilai yang telah ditetapkan oleh akademik. Sementara ada $1(10 \%)$ orang yang mengatakan mereka mampu untuk konsentrasi dalam belajar tetapi tidak sepenuhnya sampai pembelajaran selesai..

Dari fenomena diatas dapat di simpulkan secara umum mahasiswa mengalami gangguan konsentrasi belajar atau tingkat konsentrasi yang masih terbilang rendah, untuk itu perlunya penelitian untuk melihat pengaruh terapi murottal Al-qur'an terhadap peningkatan kemampuan konsentrasi belajar pada mahasiswa.

\section{Tujuan}

Penelitian ini bertujuan untuk mengetahui pengaruh terapi murottal $\mathrm{Al}$ Quran terhadap peningkatan konsentrasi pada mahasiswa prodi S1 Keperawatan tingkat II STIKes YPIB Majalengka

\section{Metode}

Penelitian ini menggunakan penelitian kuantitatif dengan menggunakan desain quasi eksperimental design dan Rancangan Non Equivalent Control Group.

Populasi dalam penelitian ini adalah seluruh mahasiswa prodi S1 Keperawatan tingkat II STIKes YPIB Majalengka tahun akademik 2019 yang berjumlah 72 mahasiswa.

Sampel dalam penelitian ini yaitu mahasiswa prodi S1 Keperawatan tingkat II STIKes YPIB Majalengka tahun akademik 2019 yang diambil dengan menggunakan 
JOURNAL OF NURSING PRACTICE AND EDUCATION

VOL. 01 No. 01, DESEMBER 2020
Ciptaan disebarluaskan di bawah

Lisensi Creative Commons Atribusi-

NonKomersial-BerbagiSerupa 4.0 Internasional. teknik sampling. Teknik sampling yang digunakan yaitu purposive sampling. 72 mahasiswa dibagi menjadi 2 kelompok, 36 mahasiswa menjadi kelompok eksperimen dan 36 mahasiswa menjadi kelompok kontrol. Variabel independen dalam penelitian ini yaitu terapi Murottal sedangkan variabel dependennya yaitu konsentrasi belajar. Alat ukur yang digunakan yaitu Army Alpha Test yang berjumlah 12 soal dan telah diuji validitas dan reliabilitasnya.

\section{Hasil Penelitian}

Penelitian ini dilakukan di Kampus STIKes YPIB Majalengka pada tanggal 01 Juli 05 Juli 2019.

Tabel 4.1 Hasil Skor Army Alpha Test pada Pretest kelompok eksperimen dan kelompok kontrol

\begin{tabular}{|c|c|c|c|c|c|c|c|}
\hline \multicolumn{2}{|c|}{$\begin{array}{c}\text { Tingkat } \\
\text { Konsentrasi } \\
\end{array}$} & Mean & Min & Max & Med & SD & $\boldsymbol{P}$ \\
\hline $\begin{array}{c}\text { Kelompok } \\
\text { Eksperimen }\end{array}$ & $\begin{array}{l}\text { Pre- } \\
\text { Test }\end{array}$ & 5.42 & 3 & 8 & 5.50 & 1.461 & \multirow{2}{*}{0.380} \\
\hline $\begin{array}{c}\text { Kelompok } \\
\text { Kontrol }\end{array}$ & $\begin{array}{l}\text { Pre- } \\
\text { Test }\end{array}$ & 5.75 & 2 & 9 & 6.00 & 1.962 & \\
\hline
\end{tabular}

Berdasarkan tabel 4.1 didapatkan rata-rata skor tingkat konsentrasi kelompok eksperimen sebelum diberikan terapi murottal Al-Qur'an adalah 5.42 dengan standar deviasi 1.461, skor konsentrasi paling tinggi 8 dan paling rendah 3 . Sedangkan pada kelompok kontrol rata-rata skor 5.75 dengan standar deviasi 1.962,

Tabel 4.2 Hasil Skor Army Alpha Test pada Post-test kelompok eksperimen dan kelompok kontrol

\begin{tabular}{|c|c|c|c|c|c|c|c|}
\hline \multicolumn{2}{|c|}{$\begin{array}{c}\text { Tingkat } \\
\text { Konsentrasi }\end{array}$} & Mean & Min & Max & Med & SD & $P$ \\
\hline $\begin{array}{c}\text { Kelompok } \\
\text { Eksperimen }\end{array}$ & $\begin{array}{l}\text { Post } \\
\text { Test }\end{array}$ & 7.58 & 5 & 11 & 7.00 & 1.591 & \multirow{2}{*}{0.000} \\
\hline $\begin{array}{c}\text { Kelompok } \\
\text { Kontrol }\end{array}$ & $\begin{array}{l}\text { Post } \\
\text { Test }\end{array}$ & 5.83 & 2 & 9 & 6.00 & 1.875 & \\
\hline
\end{tabular}

Berdasarkan tabel 4.2 didapatkan rata-rata skor tingkat konsentrasi kelompok eksperimen sesudah diberikan terapi rendah 2. Selain itu didapatkan nilai $\rho=$ 0.380 atau $\rho>0.05$ yang menunjukkan bahwa tidak ada perbedaan tingkat konsentrasi pada kelompok eksperimen dan kelompok kontrol di pengukuran awal (Pre -Test)

murottal Al-Qur'an adalah 7.58 dengan standar deviasi 1.591, skor konsentrasi paling tinggi 11 dan paling rendah 5 . 
JOURNAL OF NURSING PRACTICE AND EDUCATION

VOL. 01 No. 01, DESEMBER 2020
Ciptaan disebarluaskan di bawah

Lisensi Creative Commons Atribusi-

NonKomersial-BerbagiSerupa 4.0 Internasional.
Sedangkan pada kelompok kontrol rata-rata skor 5.83 dengan standar deviasi 1.875, skor konsentrasi paling tinggi 9 dan paling rendah 2. Selain itu didapatkan nilai $\rho=$ 0.000 atau $\rho<0.05$ yang menunjukkan bahwa ada perbedaan tingkat konsentrasi pada kelompok eksperimen dan kelompok kontrol di pengukuran di pengukuran akhir (Post-Test).

\section{Tabel 4.3 Hasil Uji Normalitas}

\begin{tabular}{ccc}
\hline Kelompok & Shapiro-Wilk \\
\hline Tingkat Konsentrasi Eksperimen Pre-Test & .026 \\
Tingkat Konsentrasi Eksperimen Post-Test & .017 \\
& Tingkat Konsentrasi Kontrol Pre-Test & .091 \\
& Tingkat Konsentrasi Kontrol Post-Test & .106 \\
\hline Uji & normalitas dengan & untuk kelompok intervensi dan kelompok
\end{tabular}

menggunakan uji Shapiro-Wilk Test kontrol yang digunakan adalah alternatif menunjukkan semua data tidak terdistribusi dari Uji T-Test yaitu Uji Wilcoxon Signed secara normal. Sehingga uji perbandingan Ranks Test.

tingkat konsentrasi pre-test dan post-test

Tabel 4.4 Hasil Uji Wilcoxon Signed Ranks Test

\begin{tabular}{ccc}
\hline Kelompok Penelitian & Jumlah (N) & Signifikasi \\
\hline $\begin{array}{c}\text { Pre-Test }- \text { Post-Test } \\
\text { Kelompok Eksperimen }\end{array}$ & $\mathbf{3 6}$ & $\mathbf{0 . 0 0 0}$ \\
$\begin{array}{c}\text { Pre-Test }- \text { Post-Test } \\
\text { Kelompok kontrol }\end{array}$ & $\mathbf{3 6}$ & $\mathbf{0 . 0 8 3}$ \\
\hline
\end{tabular}

$\begin{array}{lrl}\text { Berdasarkan hasil uji statistik } & \text { antara hasil pre-test dan post-test karena } \\ \text { dengan Wilcoxon pada kelompok } & \text { tidak diberikanny terapi murottal Al- } \\ \text { eksperimen pre-test dan post-test } & \text { Qur'an pada responden. } \\ \text { didapatkan } \rho=0.000 \text { atau } \rho<0.05 \text { berarti } & \text { PEMBAHASAN } \\ \text { terdapat perbedaan signifikan tingkat } & \text { Gambaran Tingkat Konsentrasi Pada } \\ \text { konsentrasi sebelum dan sesudah diberikan } & \text { Mahasiswa Tingkat II S1 Keperawatan } \\ \text { terapi murottal Al-Qur'an. Sedangkan pada } & \text { STIKes YPIB Majalengka Tahun 2019 } \\ \text { kelompok kontrol } \rho=0.083 \text { atau } \rho>0.05 & \text { Sebelum Pemberian Terapi Murottal Al- } \\ \text { berarti tidak terdapat perbedaan signifikan } & \text { Qur'an }\end{array}$


JOURNAL OF NURSING PRACTICE AND EDUCATION Vol. 01 No. 01, DESEMBER 2020
Ciptaan disebarluaskan di bawah

Lisensi Creative Commons Atribusi-

NonKomersial-BerbagiSerupa 4.0 Internasional
Berdasarkan hasil penelitian menunjukkan bahwa pada kelompok eksperimen, mahasiswa tidak ada yang mempunyai tingkat konsentrasi sangat rendah, mahasiswa yang mempunyai tingkat konsentrasi rendah adalah sebanyak 12 mahasiswa (33,3\%), sebagian besar responden memiliki tingkat konsentrasi sedang yaitu sebanyak 21 mahasiswa $(58,3 \%)$ dan yang mempunyai tingkat konsentrasi tinggi adalah sebanyak 3 mahasiswa $(8,3 \%)$ serta tidak ada mahasiswa yang memiliki tingkat konsentrasi sangat tinggi. Pada kelompok kontrol, sebagian besar mahasiswa juga memiliki tingkat konsentrasi sedang. Hal ini ditunjukkan dengan data tidak ada yang mempunyai tingkat konsentrasi sangat rendah, yang memiliki tingkat konsentrasi rendah adalah sebanyak 10 mahasiswa $(27,8 \%)$, mahasiswa yang memiliki tingkat konsentrasi sedang adalah sebanyak 20 mahasiswa $(55,6 \%)$ dan mahasiswa yang memiliki tingkat konsentrasi tinggi adalah sebanyak 6 mahasiswa (16,7\%), serta tidak ada mahasiswa yang memiliki tingkat konsentrasi sangat tinggi. Cara mengetahui perbedaan pre-test antara kelompok eksperimen dan kelompok kontrol, dilakukan dengan menggunakan uji statistik Mann-Whitney sehingga didapatkan hasil $\rho$
$=0.380$ atau $\rho>0.05$ artinya tidak ada perbedaan yang signifikan antara pre test pada kelompok eksperimen dan kelompok kontrol di pengukuran awal (Pre-Test).

Konsentrasi dalam belajar adalah salah satu faktor terpenting dalam mengikuti suatu proses pembelajaran supaya proses pembelajaran itu tercapai dan berhasil. Menurut Yamin, (2015) salah satu faktor yang mempengaruhi keberhasilan belajar adalah daya konsentrasi, dimana semakin memiliki daya konsentrasi yang tinggi maka akan semakin baik pencapaian tujuan belajar yang dihasilkan.

\section{Gambaran Tingkat Konsentrasi Pada} Mahasiswa Tingkat II S1 Keperawatan STIKes YPIB Majalengka Tahun 2019 Sesudah Pemberian Terapi Murottal AlQur'an.

Pada hasil penelitian post test menunjukkan bahwa pada kelompok eksperimen, sebagian besar mahasiswa mempunyai tingkat konsentrasi sedang dimana responden mahasiswa yang memiliki tingkat konsentrasi sedang adalah sebanyak 19 mahasiswa (52,8\%), responden yang memiliki tingkat konsentrasi tinggi adalah sebanyak 14 mahasiswa $(38,9 \%)$ dan responden yang memiliki tingkat konsentrasi sangat tinggi 
JOURNAL OF NURSING PRACTICE AND EDUCATION

Vol. 01 No. 01, DESEMBER 2020
Ciptaan disebarluaskan di bawah

Lisensi Creative Commons Atribusi-

NonKomersial-BerbagiSerupa 4.0

Internasional. adalah sebanyak 3 mahasiswa (8,3\%). Sedangkan pada kelompok kontrol, masih ada mahasiswa yang memiliki tingkat konsentrasi rendah. Hal ini ditunjukkan dengan data yang memiliki tingkat konsentrasi rendah adalah sebanyak 10 mahasiswa $(27,8 \% \%)$, mahasiswa yang memiliki tingkat konsentrasi sedang adalah sebanyak 20 mahasiswa $(55,6 \%)$ dan responden yang memiliki tingkat konsentrasi tinggi adalah sebanyak 6 mahasiswa (16,7\%). Cara mengetahui perbedaan post-test antara kelompok Eksperimen dan kelompok kontrol, dilakukan dengan menggunakan uji statistik Mann-Whitney sehingga didapatkan hasil $\mathrm{p}$ $=0.000$ atau $\mathrm{p}<0.05$ artinya ada perbedaan yang signifikan antara post-test pada kelompok intervensi dan kelompok kontrol di pengukuran akhir (Post-Test).

Belajar merupakan rangkaian aktivitas dilakukan untuk memperoleh suatu perubahan tingkah laku sebagai akibat dari pengalaman yang dialami dalam kehidupannya. Saat dikampus, mahasiswa disibukkan dengan berbagai agenda pembelajaran yang menuntut mahasiswa untuk dapat berkonsentrasi. Jika daya konsentrasi mahasiswa mengalami gangguan, maka akan menghambat dalam semua kegiatannya terutama dalam hal belajar. Salah satu cara untuk mengatasi gangguan konsentrasi adalah dengan terapi relaksasi. Terapi murottal Al-Qur'an adalah salah satu alternatif yang bisa digunakan untuk terapi relaksasi, karena dengan mendengarkan lantunan ayat Al-Qur'an akan memunculkan gelombang delta sebesar $63,11 \%$ yang menciptakan kenyamanan, ketenangan sehingga bisa lebih fokus untuk berkonsentrasi (Julianto et al., 2014).

Pengaruh Terapi Murottal AL-Qur'an Terhadap Peningkatan Konsentrasi Belajar Pada Mahasiswa Tingkat II S1 Keperawatan STIKes YPIB Majalengka

\section{Tahun 2019}

Cara mendapatkan pengaruh terapi murottal Al-Qur'an terhadap peningkatan konsentrasi belajar mahasiswa, didapatkan bahwa distribusi data tidak normal sehingga uji $\mathrm{T}$ berpasangan tidak dapat digunakan. Uji yang digunakan dalam penelitian ini adalah uji alternatif dari uji-T berpasangan yaitu uji Wilcoxon, sehingga didapatkan hasil pada kelompok eksperimen $\mathrm{p}=0.000$ atau $\mathrm{p}<0.05$ yang artinya pada kelompok eksperimen $\mathrm{Ha}$ diterima, berarti ada pengaruh terapi murottal Al-Qur'an terhadap peningkatan konsentrasi belajar pada mahasiswa tingkat II S1 keperawatan STIKes YPIB Majalengka. Sedangkan pada 
JOURNAL OF NURSING PRACTICE AND EDUCATION

Vol. 01 No. 01, DESEMBER 2020
Ciptaan disebarluaskan di bawah

Lisensi Creative Commons Atribusi-

NonKomersial-BerbagiSerupa 4.0 Internasional. kelompok kontrol didapatkan hasil $\mathrm{p}=$ 0.083 atau $\mathrm{p}>0.05$ yang artinya Ha ditolak berarti tidak ada pengaruh terapi murottal Al-Qur'an terhadap peningkatan konsentrasi belajar mahasiswa. Oleh karena itu, kelompok yang diberikan terapi murottal Al-Qur'an terdapat perbedaan yang signifikan, sebaliknya kelompok yang tidak diberikan terapi murottal Al-Qur'an tidak terdapat perbedaan yang signifikan. Dengan demikian dapat disimpulkan terapi murottal Al-Qur'an efektif terhadap peningkatan tingkat konsentrasi belajar mahasiswa tingkat II S1 Keperawatan STIKes YPIB Majalengka.

Setiap kegiatan belajar yang dikuatkan oleh jiwa yang tenang akan menciptakan suasana bathin yang sejuk dan menyejukan sehingga ini membawa semangat belajar yang tinggi dalam artian mampu untuk berkonsentrasi (Yamin, 2015). Menurut Abdurrochman dalam Julianto et al., (2014) Salah satu cara untuk meningkatkan konsentrasi yaitu terapi relaksasi religius dengan audio murottal (terapi murottal Al-Qur'an).

\section{Kesimpulan}

Hasil penelitian dan pembahasan mengenai "Pengaruh Terapi Murottal AlQur'an Terhadap Peningkatan Konsentrasi belajar Mahasiswa Tingkat II S1
Keperawatan STIKes YPIB Majalengka" dapat disimpulkan sebagai berikut :

Berdasarkan hasil penelitian pada pengukuran awal (Pre-Test) atau sebelum diberikannya terapi murottal Al-Qur'an didapatkan nilai $\mathrm{p}=0.380$ atau $\mathrm{p}>0.05$ yang menunjukkan tidak ada perbedaan tingkat konsentrasi pada kelompok eksperimen dan kelompok kontrol.

Berdasarkan hasil penelitian pada pengukuran akhir (Post-Test) atau setelah diberikannya terapi murottal Al-Qur'an didapatkan nilai $\mathrm{p}=0.000$ atau $\mathrm{p}<0.05$ yang menunjukkan ada perbedaan tingkat konsentrasi pada kelompok eksperimen dan kelompok kontrol.

Berdasarkan hasil penelitian didapatkan bahwa data perbandingan antara pre-test dan post-test pada kelompok kontrol didapatkan hasil dengan nilai $\mathrm{p}=$ 0,083 atau $\mathrm{p}>0,05$ yang artinya tidak ada perbedaan hasil yang signifikan karena tidak diberikan terapi murottal Al-Qur'an. Sedangkan pada kelompok eksperimen didapatkan nilai $\mathrm{p}=0,000$ atau $\mathrm{p}<0,05$ yang artinya pada kelompok eksperimen $\mathrm{Ha}$ diterima, berarti ada pengaruh terapi murottal Al-Qur'an terhadap peningkatan konsentrasi belajar pada mahasiswa tingkat II S1 keperawatan STIKes YPIB Majalengka. Sehingga dapat disimpulkan 
JOURNAL OF NURSING PRACTICE AND EDUCATION

Vol. 01 No. 01, DESEMBER 2020
Ciptaan disebarluaskan di bawah

Lisensi Creative Commons Atribusi-

NonKomersial-BerbagiSerupa 4.0 Internasional pada kelompok eksperimen ada pengaruh terapi murottal Al-Qur'an terhadap peningkatan konsentrasi belajar pada mahasiswa tingkat II S1 keperawatan STIKes YPIB Majalengka.

\section{Saran}

Bagi Institusi Pendidikan hasil penelitian ini dapat dijadikan salah satu bahan kajian referensi dan kepustakaan untuk memenuhi kebutuhan mahasiswa dalam melakukan penyusunan skripsi.

Bagi Dosen Pengajar hasil Penelitian ini diharapkan dapat menjadi masukan dalam mengembangkan pembelajaran dan dalam meningkatkan kemampuan konsentrasi belajar mahasiswa yaitu dosen pengajar dapat memberikan terapi murottal Al-Qur'an selama 15 menit sebelum pembelajaran dimulai untuk meningkatkan konsentrasi mahasiswa.

Bagi Mahasiswa hasil penelitian ini diharapkan menjadi salah satu cara dalam mengatasi gangguang konsentrasi dalam belajar yaitu dengan terapi murottal AlQur'an.

Bagi peneliti selanjutnya yang ingin meneliti lebih jauh tentang pengaruh terapi murottal Al-Qur'an terhadap peningkatan konsentrasi belajar mahasiswa, penelitian ini bisa dijadikan dasar, dengan menggunakan sampel yang lebih besar serta mengukur jenis kelamin, umur atau faktor internal dan eksternal konsentrasi belajar.

\section{Daftar Pustaka}

Aini, N. (2018). Pengaruh terapi audio murotal al Quran terhadap konsentrasi belajar pada pembelajaran Matematika. UIN Sunan Ampel Surabaya.

Julianto, V., Dzulqaidah, R. P., \& Salsabila, S. N. (2014). Pengaruh mendengarkan murattal Al Quran terhadap peningkatan kemampuan konsentrasi. Psympathic: Jurnal Ilmiah Psikologi, 1(2), 120-129.

Linasari, R. N. (2015). Upaya Peningkatan Konsentrasi Belajar Siswa Kelas IV Melalui Penerapan Teknik Kuis Tim di SD Negeri Sidomulyo Sleman Tahun Ajaran 2014/2015. Fakultas Ilmu Pendidikan Universitas Negeri Yogyakarta.

Noviati, R., Misdar, M., \& Adib, H. S. (2019). Pengaruh Lingkungan Belajar Terhadap Tingkat Konsentrasi Belajar Siswa Pada Mata Pelajaran Akidah Akhlak Di Man 2 Palembang. Jurnal PAI Raden Fatah, 1(1), 1-20.

Rahmayani, D. (2017). Faktor-faktor yang mempengaruhi konsentrasi belajar pada Mahasiswa Program Studi Ilmu Keperawatan Universitas Muhammadiyah Universitas Yogyakarta. Yogyakarta.

Riskesdas. (2018). Potret Sehat Indonesia. http://www.depkes.go.id

Rusmini, R., Mulidah, S., \& Haryati, W. (2018). Terapi Dzikir Dan Murottal Untuk Mengurangi Kecemasan Pada 
JOURNAL OF NURSING PRACTICE AND EDUCATION VOL. 01 No. 01, DESEMBER 2020

Pre Eklampsia Ringan. LINK, 14(2), 98-105.

Wuryaningsih., Emi, W. (2017). Murottal Al-Qur'an Therapy To Increase Sleep Quality In Nursing Students. UNEJ EProcedding, 7-14.

Yakub, F. (2016). Meminimalisir Perilaku
Ciptaan disebarluaskan di bawah Lisensi Creative Commons AtribusiNonKomersial-BerbagiSerupa 4.0 Internasional.

Hiperaktif Impulsif Anak Autis Melalui Intervensi Program Audio Murottal.

Yamin, M. (2015). Teori dan Metode Pembelajaran, Konsepsi, Strategi dan Praktik Belajar yang Membangun Karakter. Malang: Madani. Kelompok Intrans Publishing) Anggota IKAPI. 